\title{
Penerapan Algoritma CART Dalam Menentukan Jurusan Siswa di MAN 1 Inhil
}

\author{
Siti Monalisa ${ }^{[1]^{*}}$, Fakhri Hadi ${ }^{[2]}$ \\ Jurusan Sistem Informasi ${ }^{[1],[2]}$ \\ Fakultas Sains dan Teknologi \\ Universitas Islam Negeri Sultan Syarif Kasim Riau, Indonesia \\ siti.monalisa@uin-suska.ac.id ${ }^{[1]}$, fakhri.hadi@student.uin-suska.ac.id ${ }^{[2]}$
}

\begin{abstract}
MAN 1 Inhil is a school that applies ministerial regulations to determine the direction of student majors at the beginning of entry, namely in class $X$. Determination of majors is done by considering several indicators, namely the results of academic tests, interviews, and student interest. The calculation in determining this course is very simple, namely by adding up the values of each indicator and dividing them together so that an average value is obtained. If the value is fulfilled then the student is grouped based on their interests. This can lead to errors in decision making by the school due to subjective factors by prioritizing student interests and not based on the value of the academic test results. Therefore we need methods and algorithms to help make decisions well, the decision tree method. One algorithm that can be used is CART algorithm to classify majors with three indicators, namely Natural Sciences, Social Sciences and Religion. The results of this study indicate that the CART algorithm is able to predict correctly, from 360 data classified using the CART algorithm, it can be concluded that 71 data majoring in religion and correctly classified by CART. 144 data majoring in Natural Sciences, 119 data correctly classified and 24 data classified as IPS, and 1 data classified as religion. Of 146 data majoring in social studies, 129 were classified correctly, 16 data were classified as natural sciences. Therefore it can be concluded that CART algorithm has an $80 \%$ accuracy so that it can be used in decision making
\end{abstract}

Keywords- CART algorithm, Classification, Decission Tree,MAN 1 Inhil

\begin{abstract}
Abstrak-MAN 1 Inhil merupakan sekolah yang menerapkan peraturan menteri untuk melakukan penentuan jurusan siswa di awal masuk yaitu pada kelas X. Penentuan jurusan dilakukan dengan mempertimbangkan beberapa indikator yaitu hasil tes akademik, wawancara, dan minat siswa. Perhitungan dalam penentuan jurusan ini sangat sederhana yaitu dengan menjumlahkan nilai setiap indikator dan dibagi keseluruhannya sehingga didapatkan nilai rata-rata. Jika nilai tersebut terpenuhi maka siswa tersebut dikelompokkan berdasarkan minat nya. Hal ini bisa menimbulkan kesalahan dalam pengambilan keputusan oleh pihak sekolah karena bersifat subjektif dengan mengutamakan minat siswa dan bukan berdasarkan nilai dari hasil tes akademik. Oleh karena itu butuh metode dan algoritma dalam membantu mengambil keputusan dengan baik yaitu metode decision tree. Salah satu algoritma yang bisa digunakan yaitu algoritma CART untuk melakukan pengklasifikasian jurusan dengan tiga indikator yaitu IPA, IPS dan Agama. Hasil penelitian ini menunjukkan bahwa algoritma CART mampu melakukan prediksi dengan benar.
\end{abstract}

Berdasarkan 360 data yang diklasifikasikan disimpulkan bahwa jurusan agama terdiri dari 71 yang diklasifikasikan secara benar. Jurusan IPA berjumlah 144 meliputi 119 diklasifikasian secara benar dan 24 diklasifikasikan sebagai IPS dan 1 diklasifikasi sebagai agama. Jurusan IPS berjumlah 146 meliputi 129 diklasifikasikan secara benar dan 16 diklasifikasi sebagai IPA. Oleh karena itu dapat disimpulkan bahwa algoritma CART memiliki tingkat akurasi $80 \%$ sehingga bisa digunakan dalam pengambilan keputusan.

Kata Kunci-Algoritma CART, Decission Tree, Klasifikasi, MAN 1 Inhil

\section{PENDAHULUAN}

Saat ini penentuan jurusan pada tingkat SMA dan setingkatnya dimulai sejak siswa masuk yaitu mulai dari kelas $\mathrm{X}$. Hal ini bertujuan agar siswa lebih mendalami bidang keilmuan yang diminatinya sejak awal masuk sekolah menenah atas sehingga siswa bisa memfokuskan dirinya dalam mengembangkan kemampuan dan minat yang diminatinya. Pemilihan jurusan yang tidak tepat bisa saja merugikan siswa tersebut dan juga karirnya di masa yang akan datang [1].

Salah satu sekolah yang menerapkan sistem penjurusan tersebut adalah sekolah MAN 1 di Indragiri Hilir (Inhil) dengan jurusan yang tersedia yaitu IPA, IPS, dan MAK(Agama). Saat ini, pemilihan jurusan di MAN I Inhil dilakukan pada saat calon siswa dinyatakan lulus masuk di sekolah ini. Sistem seperti ini sangat efektif dilakukan, jika sebelumnya siswa tersebut telah memiliki persiapan dan pengetahuan mengenai jurusan yang akan dipilih. Namun sebaliknya, jika siswa tersebut belum mengetahui arah kemampuan mengenai jurusan yang akan dipilih maka siswa tersebut akan kebingungan dalam memilih jurusan dan bisa berakibat pada salah ambil jurusan.

Indikator yang digunakan oleh pihak sekolah dalam menentukan jurusan siswa adalah hasil tes akademik, wawancara, dan minat siswa. Indikator tersebut dijumlahkan dan dibagi sehingga didapat nilai rata-rata. Jika nilai tersebut terpenuhi maka siswa tersebut dikelompokkan berdasarkan minat nya. Perhitungan seperti ini sangat sederhana. Hal ini bisa menimbulkan kesalahan dalam pengambilan keputusan oleh pihak sekolah karena bersifat subjektif yaitu dengan mengutamakan minat siswa bukan berdasarkan nilai dari hasil tes akademik. 
Seringkali dijumpai dalam memilih jurusan, siswa hanya ikut-ikutan teman atau hanya memiliki informasi sedikit dari teman maupun oranglain mengenai jurusan yang dipilih. Oleh karena tidak memperhatikan nilai dan peminatan kurikulumnya sehingga menyebabkan salah jurusan dan berakibat putus sekolah di tengah jalan [2]. Terdapat beberapa hambatan yang dihadapi oleh siswa dalam memilih jurusan yaitu hambatan yang berasal dari dalam berupa kemampuan diri dan hambatan yang berasal dari luar yaitu permintaan atau paksaan orang tua dalam memilih jurusan yang mana dilatarbelakangi oleh perkerjaan di masa depan yang diharapkan oleh orang tua untuk anaknya dimasa yang akan datang [3].

Berdasarkan hasil angket yang disebarkan kepada siswa MAN 1 Inhil bahwa mayoritas siswa memperoleh jurusan berdasarkan hasil pilihan yang telah diisi pada formulir pemilihan jurusan. Selain itu, berdasarkan angket bahwa tingkat kepuasan siswa serta nilai akhir yang dihasilkanpun bervariasi, mulai dari hasil yang memuaskan hingga hasil yang kurang memuaskan. Oleh karena itu perlu adanya algoritma dalam menentukan atau memutuskan jurusan yang tepat sehingga diharapkan nilai akhir siswa mayoritas memuaskan. Metode yang bisa digunakan dalam pengambilan keputusan adalah decision tree. Salah satu algoritma yang sederhana dan kuat dalam pengambilan keputusan adalah algoritma CART [4]. Algoritma CART menghasilkan $87 \%$ tingkat akurasi data uji dan data latih [5] sehingga dapat digunakan dalam pengambilan keputusan oleh pihak sekolah dan memberikan informasi dalam menentukan jurusan yang benar [6].

\section{METODE PENELITIAN}

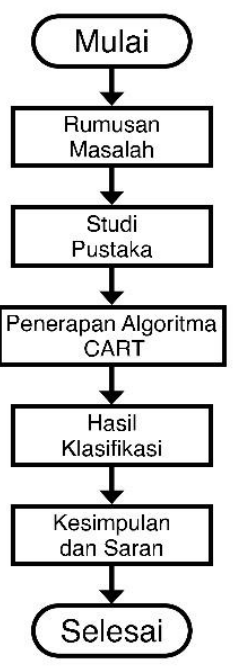

Gambar 1. Metodologi Penelitian

Metode Penelitian memberikan penjelasan tentang langkahlangkah, data, lokasi penelitian, metode evaluasi yang digunakan serta penjelasan terstruktur tentang algoritma atau metode dari penelitian yang dibahas.

Metode penelitian pada penelitian ini adalah decision tree, CART dan software WEKA yang digunakan untuk menguji hasil perhitungan manual. Metode tersebut akan dijelaskan dibawah ini.

\section{A. Pohon Keputusan (Decission Tree)}

Decission tree adalah metode pengambilan keputusan teknik klasifikasi dengan struktur flowchart yang mirip dengan pohon. Model yang dibentuk oleh metode ini ini sangat mudah dipahami sehingga menjadikan metode ini sangat umum dan popular [7]. Terdiri dari beberapa algoritma dalam membangun tree yaitu CART, ID3 dan C4.5. Penelitian ini menggunakan algoritma CART

\section{B. Algoritma CART (Classification And Regression Tree)}

Merupakan algoritma yang umum dan banyak digunakan yang mengintegrasikan berbagai faktor dari sumber yang berbeda [8] untuk masalah klasifikasi dan regresi berdasarkan biner rekursif [9]. Algoritma ini tergolong dalam model nonparametric [10] yang tidak memerlukan bentuk fungsional dan telah terbukti menjadi alat ampuh untuk masalah prediksi dan klasifikasi [9]. CART mengandalkan partisi biner rekursif [11] dari data dasar pembangunan pohon regresi. Pohon didirikan dari dataset yang dikumpulkan di simpul pohon akar dan setiap node dibagi menjadi dua node turun menggunakan variabel pemisahan (salah satu variabel prediktor). Pemilihan variabel pemisahan mencari penurunan variabilitas dalam-node dan untuk peningkatan variabilitas antara-node, dengan setiap partisi yang diperoleh menghasilkan pohon dengan variabilitas yang lebih sedikit daripada pohon sebelumnya.

Berdasarkan penelitian [6] menunjukkan bahwa berdasarkan nilai precision, nilai precission metode naive bayes lebih baik dibandingkan dengan metode yang lain dengan nilai $77,51 \%$. Sedangkan berdasarkan nilai recall dan accuracy, decision tree lebih baik dibandingkan dengan metode yang lain dengan nilai recall sebesar $90,80 \%$ dan nilai accuracy sebesar $79,14 \%[1]$.

Tahapan-tahapan yang dilakukan pada algoritma CART ini sebagai berikut [12]-[14]: Pertama, lakukan penyusunan calon cabang (candidate split) terhadap seluruh variabel prediktor dengan lengkap. Daftar yang berisi calon cabang tersebut dinamakan calon cabang mutakhir. Kedua, lakukan penilaian seluruh calon cabang mutakhir dengan melakukan perhitungan nilai besaran kesesuaian $\Phi(\mathrm{s} \mid \mathrm{t})$. Lakukan tahapan kedua sampai tidak adalagi noktah keputusan dan akan berhenti jika tidak ada lagi noktah keputusan. Untuk mencari kesesuaian $\Phi(\mathrm{s} \mid \mathrm{t})$ dari calon cabang $\mathrm{s}$ pada noktah keputusan $\mathrm{t}$ menggunakan persamaan sebagai berikut:

$$
\begin{aligned}
& \Phi(\mathrm{s} \mid \mathrm{t})=2 \mathrm{P}_{\mathrm{L}} \mathrm{P}_{\mathrm{R}} \mathrm{Q}(\mathrm{s} \mid \mathrm{t}) \ldots \ldots \ldots \ldots \ldots \ldots \ldots \ldots \ldots \ldots \ldots \ldots \\
& \text { Dimana } \mathrm{Q}(\mathrm{s} \mid \mathrm{t})=\sum_{i=1}^{J u m l a h} \mid P(j \mid \mathrm{tL})-P(j \mid \mathrm{tR})
\end{aligned}
$$

$\mathrm{t}_{\mathrm{L}}=$ cabang kiri dari noktah keputusan $\mathrm{t}$

$t_{R}=$ cabang kanan dari noktah keputusan $t$

dimana

$$
\begin{aligned}
& \mathrm{P}_{\mathrm{L}}=\frac{\text { jumlah catatan pada calon kiri } \mathrm{t} L}{\text { jumlah catatan pada data latihan }} . . \\
& \mathrm{P}\left(\mathrm{j} \mid \mathrm{t}_{\mathrm{L}}=\frac{j \text { calon cabang kiri t } L}{\text { noktah keputusant }} \ldots \ldots \ldots\right. \\
& \mathrm{P}_{\mathrm{L}}=\frac{\text { jumlah catatan pada calon kirit } \mathrm{R}}{\text { jumlah catatan pada data latihan }} . . \\
& \mathrm{P}\left(\mathrm{j} \mid \mathrm{t}_{\mathrm{R}}\right)=\frac{j \text { calon cabang kirit } R}{\text { noktah keputusan }} \ldots \ldots \ldots \ldots
\end{aligned}
$$




\section{Weka Tools}

WEKA merupakan salah satu tools yang mampu melakukan perbandingan beberapa algoritma machine learning yang digunakan dalam pengaplikasian pada permasalahan data mining. Tools ini bisa dikembangkan oleh siapa saja karena bersifat open source dan dikembangkan pertamakali oleh University of Wakaito di Selandia Baru [15] sebagai penambangan data. Pada tools ini, data-data di uji prosedurprosedurnya untuk melakukan eksplorasi dan permodelan guna menghasilkan hubungan yang tersembunyi dari data tersebut [16].

\section{HASIL DAN PEMBAHASAN}

Data inputan berjumlah 439 record yang berasal dari data rekapitulasi pendaftaran dan seleksi siswa kelas X. Adapun target dan klasifikasi dalam penentuan jurusan menggunakan atribut seperti Jenis Kelamin, Nilai Tes Siswa berupa Nilai Matematika, IPA, IPS dan Agama, ditunjukkan pada TABEL I.

TABLE I. DATA REKAPUTULASI (POTONGAN DATA)

\begin{tabular}{|l|l|l|l|l|l|c|}
\hline No. & Nama & JK & $\begin{array}{l}\text { MT } \\
\text { K }\end{array}$ & IPS & $\ldots$ & Jurusan \\
\hline 1. & Muh Ariansyah & LK & 85 & 75 & $\ldots$ & Agama \\
\hline 2. & Robiansyah & LK & 70 & 85 & $\ldots$ & Agama \\
\hline 3. & M.Hidayat & PR & 90 & 70 & $\ldots$ & Agama \\
\hline$\ldots$ & $\ldots$ & $\ldots$ & $\ldots$ & $\ldots$ & $\ldots$ & $\ldots$ \\
\hline 439 & Muhammad Ridho & LK & 0 & 0 & 0 & Tidak Lulus \\
\hline
\end{tabular}

\section{A. Preprocessing Data}

Tahapan ini bertujuan untuk memilih data dan atribut yang sesuai dan lengkap. Awalnya tribut berjumlah 11, namun setelah dilakukan penyeleksian dan pembersihan data menjadi 8 atribut yang dapat digunakan. Atribut seperti peringkat, nilai rata-rata, dan keterangan lulus/tidak lulus dihapus dan tidak digunakan. Selain itu, data yang digunakan berjumlah 360 record dari yang sebelumnya berjumlah 439 record data. Data hasil pada tahap ini di tunjukkan pada TABEL II.

TABLE II. DATA HASIL PREPROCESSING (POTONGAN DATA)

\begin{tabular}{|l|l|l|l|l|l|c|}
\hline No. & Nama & JK & MTK & $\begin{array}{l}\text { IP } \\
\text { S }\end{array}$ & $\ldots$ & Jurusan \\
\hline 1. & Muh Ariansyah & LK & 85 & 75 & $\ldots$ & Agama \\
\hline 2. & Robiansyah & LK & 70 & 85 & $\ldots$ & Agama \\
\hline 3. & M.Hidayat & PR & 90 & 70 & $\ldots$ & Agama \\
\hline$\ldots$ & $\ldots$ & $\ldots$ & $\ldots$ & $\ldots$ & $\ldots$ & $\ldots$ \\
\hline 360 & Selfi Nurdiati & PR & 25 & 25 & $\ldots$ & IPS \\
\hline
\end{tabular}

\section{B. Data Latih Dan Data Uji}

Berdasarkan data yang dihasilkan pada TABEL II selanjutnya digunakan 15 data latih pada TABEL III. Selanjutnya akan dilakukan pengujian data dengan mencari label atau jurusanya berdasarkan perhitungan algoritma CART. Data uji pada penelitian ini di tunjukkan pada TABEL IV.
TABLE III. DATA LATIH

\begin{tabular}{|c|l|l|l|l|l|l|c|}
\hline No. & Nama & JK & \multicolumn{1}{l|}{ MTK } & IPA & $\ldots$ & JUR \\
\hline 1 & Muh Weldi & LK & 70 & 85 & $\ldots$ & AGAMA \\
\hline 2 & Cici Alia & PR & 60 & 90 & $\ldots$ & AGAMA \\
\hline 3 & Syaifira A & PR & 65 & 90 & $\ldots$ & IPA \\
\hline 4 & Nia Zufiani & PR & 65 & 85 & $\ldots$ & IPA \\
\hline 5 & $\begin{array}{l}\text { Abdul } \\
\text { Rahman }\end{array}$ & LK & 60 & 80 & $\ldots$ & IPA \\
\hline 6 & Muh Rizki & LK & 60 & 61,43 & $\ldots$ & AGAMA \\
\hline 7 & Muh Arya & LK & 55 & 70 & $\ldots$ & AGAMA \\
\hline 8 & Meilani S & PR & 45 & 52,86 & $\ldots$ & AGAMA \\
\hline 9 & Widia Putri & PR & 50 & 44,29 & $\ldots$ & IPA \\
\hline 10 & Ihsan D & LK & 60 & 47,14 & $\ldots$ & IPA \\
\hline 11 & Meiry M & PR & 45 & 52,86 & $\ldots$ & IPS \\
\hline 12 & Windi A & PR & 35 & 52,86 & $\ldots$ & IPS \\
\hline 13 & Puspa Y & PR & 30 & 47,14 & $\ldots$ & IPS \\
\hline 14 & Suandi & PR & 35 & 52,86 & $\ldots$ & IPS \\
\hline 15 & Tirta & PR & 45 & 47,14 & & IPS \\
\hline
\end{tabular}

TABLE IV. DATA UJI

\begin{tabular}{|l|l|l|l|l|l|l|l|}
\hline No. & $\begin{array}{l}\text { Na } \\
\text { ma }\end{array}$ & JK & MTK & $\begin{array}{l}\text { IP } \\
\text { A }\end{array}$ & IPS & AGAMA & JUR \\
\hline 1 & $\begin{array}{l}\text { Muh } \\
\text { Reza }\end{array}$ & LK & 75 & 75 & 58,71 & 82,98 & $?$ \\
\hline
\end{tabular}

\section{Penerapan Metode Cart}

Tahapan pertama pada Algoritma CART ini adalah menentukan calon noktah keputusan dengan cara menyusun calon cabang (candidate split) yang dilakukan terhadap seluruh atribut prediktor yaitu Jenis Kelamin, Rata-rata nilai IPA, Ratarata nilai IPS, Rata-rata nilai Agama, Rata-rata nilai Matematika, sehingga terbentuk daftar calon cabang mutakhir seperti yang ditunjukkan pada TABEL V.

TABLE V. DAFTAR CALON MUTAKHIR

\begin{tabular}{|c|c|c|}
\hline $\begin{array}{c}\text { Nomor } \\
\text { calon } \\
\text { cabang }\end{array}$ & Calon cabang kiri $\left(\mathbf{t}_{\mathbf{L}}\right)$ & Calon cabang kanan $\left(\mathbf{t}_{\mathbf{R}}\right)$ \\
\hline 1 & Jenis Kelamin = Laki-laki & $\begin{array}{c}\text { Jenis Kelamin }= \\
\text { Perempuan }\end{array}$ \\
\hline 2 & Rata-rata nilai IPA $\leq 50$ & Rata-rata nilai IPA $>50$ \\
\hline 3 & Rata-rata nilai IPA $\leq 80$ & Rata-rata nilai IPA $>80$ \\
\hline 4 & Rata-rata nilai IPS $\leq 50$ & Rata-rata nilai IPS $>50$ \\
\hline 5 & Rata-rata nilai IPS $\leq 60$ & Rata-rata nilai IPS $>60$ \\
\hline 6 & Rata-rata nilai Agama $\leq 60$ & Rata-rata nilai Agama $>60$ \\
\hline 7 & Rata-rata nilai Agama $\leq 80$ & Rata-rata nilai Agama $>80$ \\
\hline 8 & $\begin{array}{c}\text { Rata-rata nilai Matemtika } \\
\leq 30\end{array}$ & $\begin{array}{c}\text { Rata-rata nilai Matematika } \\
>30\end{array}$ \\
\hline 9 & $\begin{array}{c}\text { Rata-rata nilai Matematika } \\
\leq 50\end{array}$ & $\begin{array}{c}\text { Rata-rata nilai Matematika } \\
>50\end{array}$ \\
\hline
\end{tabular}

Data yang telah diolah pada Tabel 5 selanjutnya di seleksi berdasarkan data latih sehingga menghasilkan data calon mutakhir pada TABEL VI. 
TABLE VI. DATA CALON MUTAKHIR

\begin{tabular}{|c|c|c|}
\hline $\begin{array}{c}\text { Nomor Calon } \\
\text { Cabang }\end{array}$ & $\begin{array}{c}\text { Calon Cabang Kiri } \\
(\mathbf{t L})\end{array}$ & $\begin{array}{c}\text { Calon Cabang Kanan } \\
(\mathbf{t R})\end{array}$ \\
\hline 1 & 8 & 7 \\
\hline 2 & 7 & 8 \\
\hline 3 & 11 & 11 \\
\hline 4 & 4 & 6 \\
\hline 5 & 9 & 10 \\
\hline 6 & 5 & 6 \\
\hline 7 & 9 & 11 \\
\hline 8 & 4 & 8 \\
\hline 9 & 7 & 4 \\
\hline
\end{tabular}

Setelah mendapatkan calon cabang kiri dan kanan, selanjutnya menghitung candidate split purity left $\left(\mathrm{P}_{\mathrm{L}}\right)$ dan purity right $\left(\mathrm{P}_{\mathrm{R}}\right)$ dengan menggunakan persamaan (3) dan (5) sehingga menghasilkan nilai yang ada pada TABEL VII.

TABLE VII. NILAI $P_{L}$ DAN $P_{R}$

\begin{tabular}{|l|l|l|}
\hline No & $\mathbf{P}_{\mathbf{L}}$ (Purity Left) & $\mathbf{P}_{\mathbf{R}}$ (Purity Right) \\
\hline 1 & $8: 15=0,5333$ & $7: 15=0,4667$ \\
\hline 2 & $7: 15=0,4667$ & $8: 15=0,5333$ \\
\hline 3 & $11: 15=0,7333$ & $4: 15=0,2667$ \\
\hline 4 & $4: 15=0,2667$ & $11: 15=0,7333$ \\
\hline 5 & $9: 15=0,6000$ & $6: 15=0,4000$ \\
\hline 6 & $5: 15=0,3333$ & $10: 15=0,6667$ \\
\hline 7 & $9: 15=0,6000$ & $6: 15=0,4000$ \\
\hline 8 & $4: 15=0,2667$ & $11: 15=0,7333$ \\
\hline 9 & $7: 15=0,4667$ & $8: 15=0,5333$ \\
\hline
\end{tabular}

Selanjutnya melakukan penandaan pada label kelas menggunakan persamaan (4) dan (6) untuk jurusan IPA,IPS dan AGAMA. Sehingga menghasilkan perhitungan pada TABEL VIII.

TABLE VIII. NILAI $\left(j \mid T_{L}\right)$ dan $P\left(j \mid T_{R}\right)$

\begin{tabular}{|c|c|c|c|}
\hline $\begin{array}{l}\mathbf{N} \\
\mathbf{0}\end{array}$ & Jurusan & $\underline{P\left(j \mid T_{L}\right)}$ & $\underline{P\left(j \mid T_{R}\right)}$ \\
\hline \multirow[t]{3}{*}{1} & IPA & $3 / 8=0,3750$ & $2 / 7=0,2857$ \\
\hline & IPS & $2 / 8=0,2500$ & $3 / 7=0,4286$ \\
\hline & AGAMA & $3 / 8=0,3750$ & $2 / 7=0,2857$ \\
\hline \multirow[t]{3}{*}{2} & IPA & $1 / 7=0,1429$ & $4 / 8=0,5000$ \\
\hline & IPS & $5 / 7=0,7143$ & $0 / 8=0,0000$ \\
\hline & AGAMA & $1 / 7=0,1429$ & $4 / 8=0,5000$ \\
\hline \multirow[t]{3}{*}{3} & IPA & $3 / 11=0,2727$ & $2 / 4=0,5000$ \\
\hline & IPS & $5 / 11=0,4545$ & $0 / 4=0,0000$ \\
\hline & AGAMA & $3 / 11=0,2727$ & $2 / 4=0,5000$ \\
\hline \multirow[t]{3}{*}{4} & IPA & $2 / 4=0,5000$ & $3 / 11=0,2727$ \\
\hline & IPS & $2 / 4=0,5000$ & $3 / 11=0,2727$ \\
\hline & AGAMA & $0 / 4=0,0000$ & $5 / 11=0,4545$ \\
\hline \multirow[t]{3}{*}{5} & IPA & $3 / 9=0,3333$ & $2 / 6=0,3333$ \\
\hline & IPS & $5 / 9=0,5556$ & $5 / 9=0,5556$ \\
\hline & AGAMA & $1 / 9=0,1111$ & $4 / 6=0,6667$ \\
\hline \multirow[t]{2}{*}{6} & IPA & $0 / 5=0,0000$ & $5 / 10=0,5000$ \\
\hline & IPS & $5 / 5=1,0000$ & $0 / 10=0,0000$ \\
\hline
\end{tabular}

\begin{tabular}{|c|c|c|c|}
\hline $\begin{array}{l}\mathbf{N} \\
\mathbf{0}\end{array}$ & Jurusan & $\underline{\boldsymbol{P}\left(j \mid T_{L}\right)}$ & $\underline{P\left(j \mid T_{R}\right)}$ \\
\hline & AGAMA & $0 / 5=0,0000$ & $5 / 10=0,5000$ \\
\hline \multirow[t]{3}{*}{7} & IPA & $4 / 9=0,4444$ & $1 / 6=0,1667$ \\
\hline & IPS & $5 / 9=0,5556$ & $0 / 6=0,0000$ \\
\hline & AGAMA & $0 / 9=0,0000$ & $5 / 6=0,8333$ \\
\hline \multirow[t]{3}{*}{8} & IPA & $0 / 4=0,0000$ & $5 / 11=0,4545$ \\
\hline & IPS & $4 / 4=1,0000$ & $1 / 11=0,0909$ \\
\hline & AGAMA & $0 / 4=0,0000$ & $5 / 11=0,4545$ \\
\hline \multirow[t]{3}{*}{9} & IPA & $1 / 7=0,1429$ & $4 / 8=0,5000$ \\
\hline & IPS & $5 / 7=0,7143$ & $0 / 8=0,0000$ \\
\hline & AGAMA & $1 / 7=0,1429$ & $4 / 8=0,5000$ \\
\hline
\end{tabular}

Selanjutnya persamaan 2 digunakan untuk mencari nilai $Q$ $(s \mid t)$ dengan cara mencari selisih nilai $P\left(j \mid T_{L}\right)$ dan $P\left(j \mid T_{R}\right)$ pada setiap label atau jurusan dan nilai yang dihasilkan bersifat absolute lalu selanjutnya hasil selisihnya dijumlahkan. Sehingga menghasilkan nilai $Q(s \mid t)$ seperti ditunjukkan pada TABEL IX.

Berdasarkan TABEL IX, selanjutnya dihitung nilai kesesuain (goodness) calon cabang $\varphi(s \mid t)$ menggunakan Persamaan 2 dengan mengalikan nilai $2 P_{L} P_{R}$ dan $Q(s \mid t)$. Nilai $2 P_{L} P_{R}$ didapat dari $\left(2 P_{L} \times P_{R}\right)$ kalikan 2 . Hasil perhitungannya ditunjukkan pada TABEL $X$.

Calon cabang tertinggi berada pada nomor calon cabang ke 6 yaitu 0,8889 berdasarkan TABEL $X$ diatas. Nilai yang dihasilkan pada calon cabang kiri Rata-rata nilai Agama $\leq 60$ dan calon cabang kanan Rata-rata nilai Agama >60 sehingga calon cabang inilah yang dipilih sebagai root node pada tahap ini. Namun, tetap dilakukan perhitungan kembali sampai memiliki noktah keputusan dengan iterasi selanjutnya, setelah menghilangkan no 6 yang terpilih sebelumnya. Hal ini akan menghasilkan jumlah kesesuian hasil prediksi jurusan yang memilih jurusan IPA dan IPS dan Agama. Perhitungan iterasi terakhir ditunjukkan pada Gambar I. yang menghasilkan pohon keputusan.

TABLE IX. DATA PERHITUNGAN $Q(s \mid t)$

\begin{tabular}{|c|c|c|c|c|c|}
\hline No & Jurusan & $\mathbf{P}\left(\mathbf{j} \mid \mathbf{T}_{\mathrm{L}}\right)$ & $\mathbf{P}\left(\mathbf{j} \mid \mathbf{T}_{\mathrm{R}}\right)$ & $\begin{array}{c}\text { Selisih } \\
\text { (Absolute) }\end{array}$ & $\mathbf{Q}(\mathbf{s} \mid \mathbf{t})$ \\
\hline \multirow[t]{3}{*}{1} & IPA & 0,375 & 0,2857 & 0,0893 & \multirow[t]{3}{*}{0,3571} \\
\hline & IPS & 0,25 & 0,4286 & 0,1786 & \\
\hline & AGAMA & 0,375 & 0,2857 & 0,0893 & \\
\hline \multirow[t]{3}{*}{2} & IPA & 0,1429 & 0,5 & 0,3571 & \multirow[t]{3}{*}{1,4286} \\
\hline & IPS & 0,7143 & 0 & 0,7143 & \\
\hline & AGAMA & 0,1429 & 0,5 & 0,3571 & \\
\hline \multirow[t]{3}{*}{3} & IPA & 0,2727 & 0,5 & 0,2273 & \multirow[t]{3}{*}{0,9091} \\
\hline & IPS & 0,4545 & 0 & 0,4545 & \\
\hline & AGAMA & 0,2727 & 0,5 & 0,2273 & \\
\hline \multirow[t]{3}{*}{4} & IPA & 0,5 & 0,2727 & 0,2273 & \multirow[t]{3}{*}{0,9091} \\
\hline & IPS & 0,5 & 0,2727 & 0,2273 & \\
\hline & AGAMA & 0 & 0,4545 & 0,4545 & \\
\hline \multirow[t]{3}{*}{5} & IPA & 0,3333 & 0,3333 & 0 & \multirow[t]{3}{*}{1,1111} \\
\hline & IPS & 0,5556 & 0 & 0,5556 & \\
\hline & AGAMA & 0,1111 & 0,6667 & 0,5556 & \\
\hline \multirow[t]{3}{*}{6} & IPA & 0 & 0,5 & 0,5 & \multirow[t]{3}{*}{2} \\
\hline & IPS & 1 & 0 & 1 & \\
\hline & AGAMA & 0 & 0,5 & 0,5 & \\
\hline
\end{tabular}




\begin{tabular}{|c|c|c|c|c|c|}
\hline No & Jurusan & $\mathbf{P}\left(\mathbf{j} \mid \mathbf{T}_{\mathrm{L}}\right)$ & $\mathbf{P}\left(\mathbf{j} \mid \mathbf{T}_{\mathrm{R}}\right)$ & $\begin{array}{c}\text { Selisih } \\
\text { (Absolute) }\end{array}$ & $\mathbf{Q}(\mathbf{s} \mid \mathbf{t})$ \\
\hline \multirow[t]{3}{*}{7} & IPA & 0,4444 & 0,1667 & 0,2778 & \multirow[t]{3}{*}{1,6667} \\
\hline & IPS & 0,5556 & 0 & 0,5556 & \\
\hline & AGAMA & 0 & 0,8333 & 0,8333 & \\
\hline \multirow[t]{3}{*}{8} & IPA & 0 & 0,4545 & 0,4545 & \multirow[t]{3}{*}{1,8182} \\
\hline & IPS & 1 & 0,0909 & 0,9091 & \\
\hline & AGAMA & 0 & 0,4545 & 0,4545 & \\
\hline \multirow[t]{3}{*}{9} & IPA & 0,1429 & 0,5 & 0,3571 & \multirow[t]{3}{*}{1,4286} \\
\hline & IPS & 0,7143 & 0 & 0,7143 & \\
\hline & AGAMA & 0,1429 & 0,5 & 0,3571 & \\
\hline
\end{tabular}

TABLE X. DATA PERHITUNGAN $Q(s \mid t)$

\begin{tabular}{|c|c|c|c|}
\hline No & $\underline{\mathbf{P}}_{L} \underline{\boldsymbol{P}}_{R}$ & $\underline{\boldsymbol{Q}(\boldsymbol{s} \mid \boldsymbol{t})}$ & $\underline{\underline{\boldsymbol{(}(\boldsymbol{s} \mid \boldsymbol{t})}}$ \\
\hline 1 & 0,4978 & 0,3571 & 0,1778 \\
\hline 2 & 0,4978 & 1,4286 & 0,7111 \\
\hline 3 & 0,3911 & 0,9091 & 0,3556 \\
\hline 4 & 0,3911 & 0,9091 & 0,3556 \\
\hline 5 & 0,48 & 1,1111 & 0,5333 \\
\hline 6 & 0,4444 & 2 & 0,8889 \\
\hline 7 & 0,48 & 1,6667 & 0,8 \\
\hline 8 & 0,3911 & 1,8182 & 0,7111 \\
\hline 9 & 0,4978 & 1,4286 & 0,7111 \\
\hline
\end{tabular}

Berdasarkan TABEL IX, selanjutnya dihitung nilai kesesuain (goodness) calon cabang $\varphi(s \mid t)$ menggunakan Persamaan 2 dengan mengalikan nilai $2 P_{L} P_{R}$ dan $Q(s \mid t)$. Nilai $2 P_{L} P_{R}$ didapat dari $\left(2 P_{L} \times P_{R}\right)$ kalikan 2 . Hasil perhitungannya ditunjukkan pada TABEL $X$.

Calon cabang tertinggi berada pada nomor calon cabang ke 6 yaitu 0,8889 berdasarkan TABEL $\mathrm{X}$ diatas. Nilai yang dihasilkan pada calon cabang kiri Rata-rata nilai Agama $\leq 60$ dan calon cabang kanan Rata-rata nilai Agama >60 sehingga calon cabang inilah yang dipilih sebagai root node pada tahap ini. Namun, tetap dilakukan perhitungan kembali sampai memiliki noktah keputusan dengan iterasi selanjutnya, setelah menghilangkan no 6 yang terpilih sebelumnya. Hal ini akan menghasilkan jumlah kesesuian hasil prediksi jurusan yang memilih jurusan IPA dan IPS dan Agama. Perhitungan iterasi terakhir ditunjukkan pada Gambar I. yang menghasilkan pohon keputusan.

Iterasi selanjutnya adalah Calon cabang nomor 7 yang memiliki nilai tertinggi. Nilai yang dihasilkan adalah calon cabang kiri rata-rata nilai agama $\leq 80$ dan calon cabang kanan > 80 sehingga dijadikan cabang kedua. Masing-masing cabang memiliki keterangan yang berbeda. Pada cabang dengan nilai rata-rata agama $\leq 80$ memiliki keterangan yang homogen maka proses pencabangan dihentikan, untuk cabang dengan nilai rata-rata aga- ma > 80 memiliki keterangan belum homogen tetapi sudah memenuhidari dari seluruh data latih yaitu 15 data, maka proses pencabangan juga dihentikan. Selanjutnya dilakukan pengklasifikasian data uji pada TABEL XI.

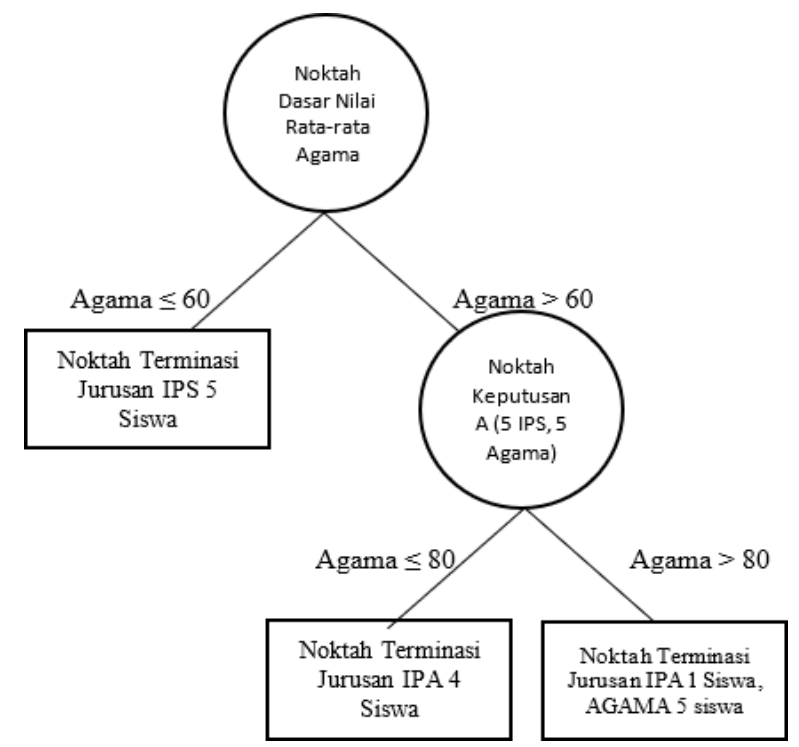

Gambar 2. Hasil pohon keputusan akhir

TABLE XI. DATA UJI

\begin{tabular}{|c|c|c|c|c|c|c|}
\hline Nama & MTK & IPA & IPS & Agama & Jurusan & Prediksi \\
\hline $\begin{array}{c}\text { Muh } \\
\text { Reza }\end{array}$ & 75 & 75 & 58,71 & 82,98 & Agama & $?$ \\
\hline
\end{tabular}

Berdasarkan kesimpulan rule, rata-rata nilai agama merupakan nilai yang diprioritaskan terlebih dahulu untuk menentukan jurusan. Siswa yang bernama Muhammad Muh Reza tidak memenuhi syarat dikarenakan rata-rata nilai agama $\leq 60$ sehingga tidak memenuhi masuk jurusan IPS, rata-rata nilai agama $\leq 80$ sehingga tidak memenuhi masuk jurusan IPA, rata-rata nilai agama > 80 sehingga memenuhi masuk jurusan Agama. Sehingga disimpulkan bahwa jurusan yang cocok untuk Muhammad Muh Reza adalah Agama. Hasilnya ditunjukkan pada TABEL XII.

TABLE XII. DATA UJI PREDIKSI

\begin{tabular}{|c|c|c|c|c|c|c|}
\hline Nama & MTK & IPA & IPS & Agama & Jurusan & Prediksi \\
\hline $\begin{array}{c}\text { Muh } \\
\text { Reza }\end{array}$ & 75 & 75 & 58,71 & 82,98 & Agama & Agama \\
\hline
\end{tabular}

\section{Pengujian Tools Weka}

Menggunakan 15 data maka dilakukan pengujian algoritma Cart pada tools Weka. Hasilnya sebagai berikut :

AGAMA <59.72: IPS (5/0) AGAMA $\geq 59.72$

- AGAMA <78.38: IPA (4/0)

- AGAMA $\geq 78.38$

— - IPA <87.5: AGAMA (4/0)

- IPA $\geq 87.5$

—— - IPS <62.86: IPA (1/0)

- — - IPS $\geq 62.86:$ AGAMA $(1 / 0)$ 


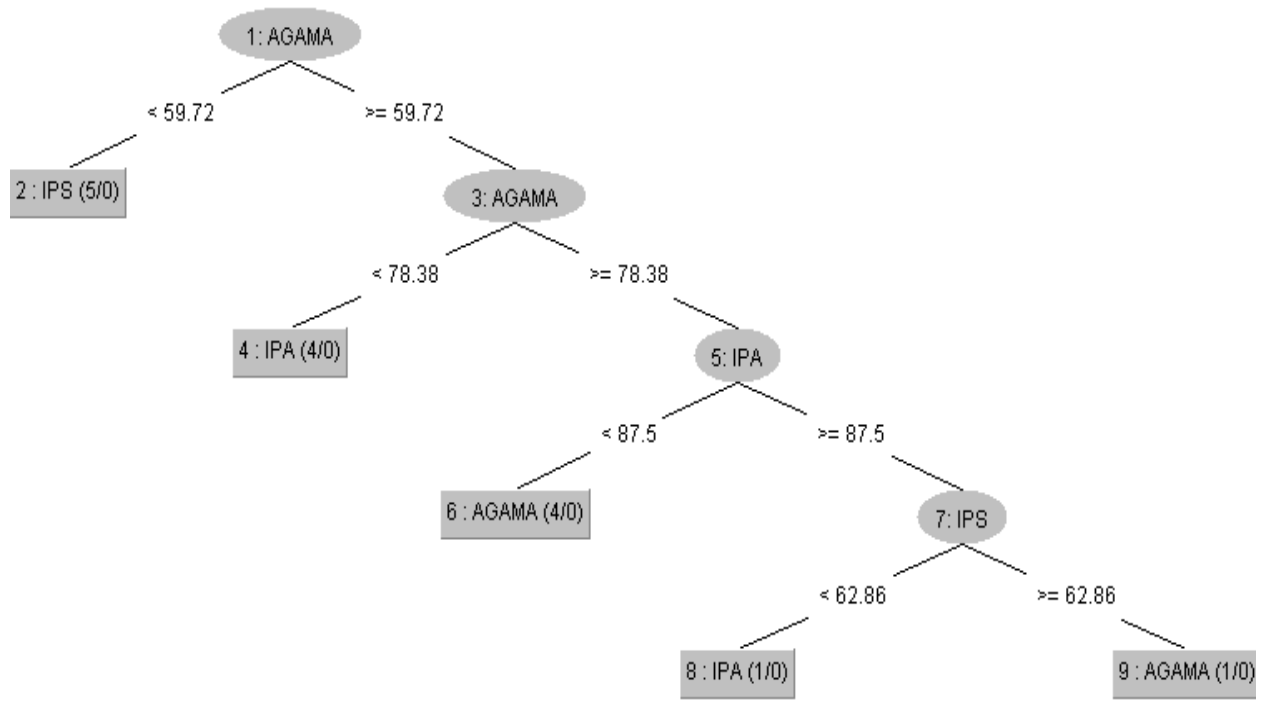

Gambar 3. Pohon Visualisasi dengan Weka

Pohon visualisasi Algoritma CART dapat dilihat pada Gambar II. dan hasil prediksi dari kesimpulan rule ditunjukkan pada TABEL XIII. Sedangkan Uji coba tingkat akurasi ditunjukkan pada TABEL XIV dengan akurasi yang tergolong tinggi yaitu $80 \%$.

TABLE XIII. HASIL PREDIKSI DATA UJI

\begin{tabular}{|l|l|l|l|l|l|l|l|}
\hline No & NAMA & IPA & IPS & Agama & MTK & Prediksi & Jurusan \\
\hline 1 & Syaifira & 90.0 & 58.57 & 84.26 & 65.0 & AGAMA & IPA \\
\hline 2 & Meiry M & 45.0 & 52.86 & 51.18 & 15.0 & IPS & IPS \\
\hline 3 & Cici A & 90.0 & 67.14 & 94.74 & 60.0 & AGAMA & AGAMA \\
\hline 4 & Nia Z & 85.0 & 75.71 & 65.15 & 65.0 & IPA & IPA \\
\hline 5 & Suandi & 35.0 & 52.86 & 48.05 & 25.0 & IPS & IPS \\
\hline 6 & Muhammad Rizqi A & 60.0 & 61.43 & 97.87 & 60.0 & AGAMA & AGAMA \\
\hline 7 & Wilia Permata A & 50.0 & 44.29 & 72.5 & 80.0 & IPA & IPA \\
\hline 8 & Windi A & 35.0 & 52.86 & 54.49 & 20.0 & IPS & IPS \\
\hline 9 & Meileny S & 45.0 & 52.86 & 89.04 & 65.0 & IPS & AGAMA \\
\hline 10 & Ihsan D & 60.0 & 47.14 & 64.96 & 45.0 & IPA & IPA \\
\hline 11 & Tirta A Pratama & 45.0 & 47.14 & 46.76 & 20.0 & IPS & IPS \\
\hline 12 & M Arya Y & 55.0 & 70.0 & 84.08 & 45.0 & IPS & AGAMA \\
\hline 13 & Abdul R Sidiq & 80.0 & 70.0 & 72.68 & 60.0 & IPA & IPA \\
\hline 14 & Puspa Y & 30.0 & 47.14 & 45.11 & 40.0 & IPS & IPS \\
\hline
\end{tabular}

TABLE XIV. NILAI AKURASI ALGORITMA CART)

\begin{tabular}{|c|c|c|}
\hline No. & Jenis & Persentase \\
\hline 1 & Akurasi & $80 \%$ \\
\hline 2 & Precision & 0,794 \\
\hline 3 & Recall & 0,8 \\
\hline
\end{tabular}

Berdasarkan node akar yang telah diperoleh terjadi perbedaan antara perhitungan manual dan tools Weka. Pada perhitungan manual diperoleh Nilai Agama $\leq 60$ dan Nilai Agama > 60. Perhitungan Tools Weka diperoleh Nilai Agama > 59.72 dan Nilai Agama $\geq 59,72$. Perbedaan ini terjadi karena ketika pembentukan Calon cabang mutakhir pada perhitungan manual yang terdapat pada TABEL V berbeda dengan cara perhitungan Tools Weka, karena pembentukan Calon cabang mutakhir ini yang bersifat subjektif. 


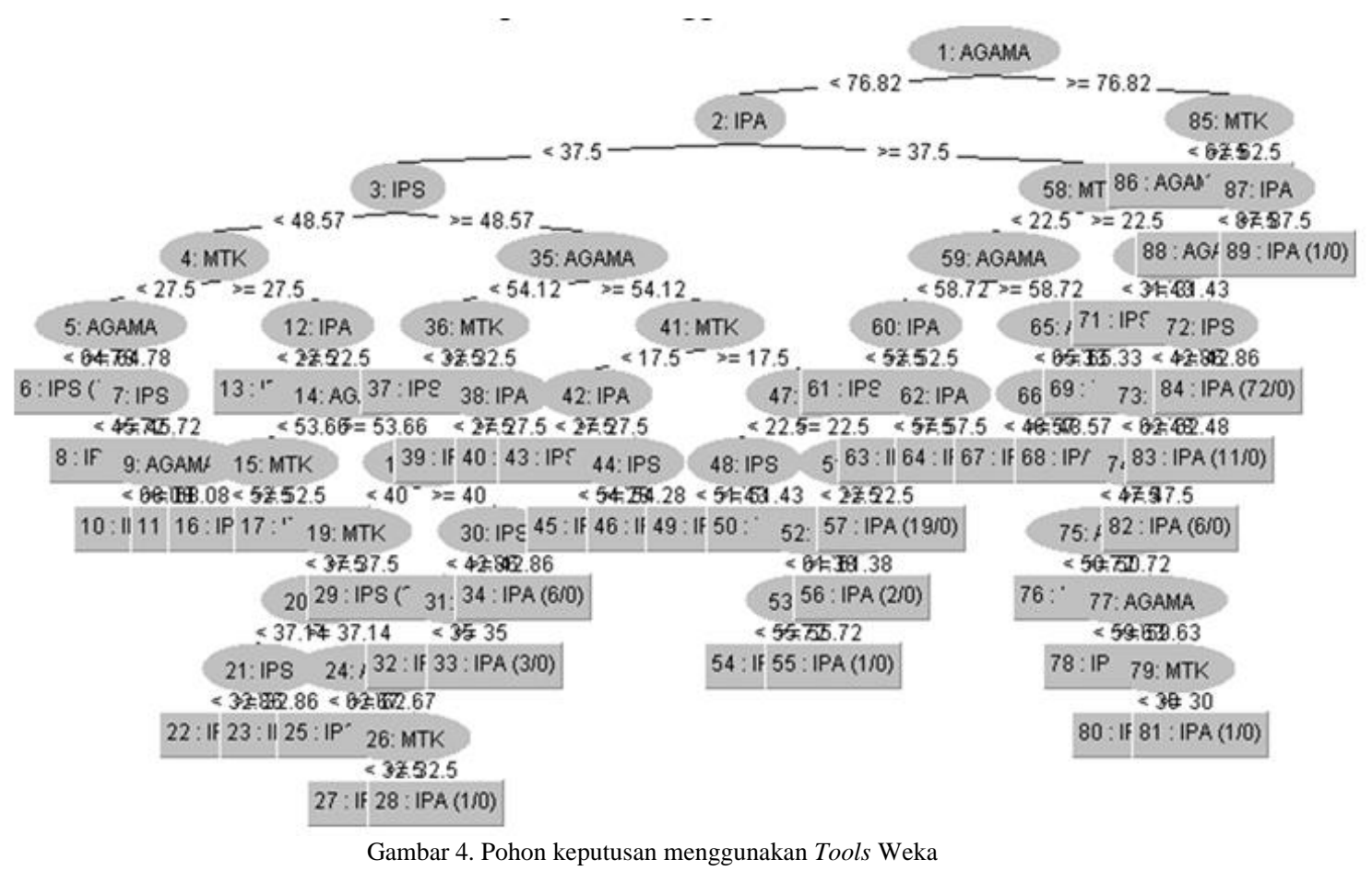

Tahapan selanjutnya melakukan Uji coba seluruh data dengan Tools Weka. Sehingga terbentuklah Node dari pohon keputusan sebagai berikut : Jumlah Node Akar yaitu 1 node, jumlah Node Internal yaitu 43 node, jumlah Lengan yaitu 89 lengan dan jumlah Node Daun (Internal) yaitu 49 node. Untuk melihat Pohon Visualisasi keseluruhan data ditunjukkan pada Gambar III. dan untuk melihat hasil klasifikasi dari kesimpulan rule dan pohon yang terbentuk dapat dilihat pada TABEL XV.

TABLE XV. HASIL KESIMPULAN RULE

\begin{tabular}{|l|l|l|l|l|l|c|c|}
\hline No & NAMA & IPA & IPS & Agama & MTK & Prediksi & Jurusan \\
\hline 1 & Himantul & 45.0 & 45.0 & 78.57 & 58.71 & IPA & IPA \\
\hline 2 & Muh Andri & 30.0 & 35.0 & 47.14 & 60.0 & IPS & IPA \\
\hline 3 & Murniyanti & 50.0 & 50.0 & 38.57 & 58.9 & IPA & IPA \\
\hline 4 & Nursiffa Z & 40.0 & 30.0 & 41.43 & 62.76 & IPS & IPA \\
\hline 5 & Muh Yusof & 25.0 & 35.0 & 47.14 & 64.96 & IPS & IPA \\
\hline 6 & Aura Putri & 20.0 & 55.0 & 70.0 & 67.35 & IPA & IPA \\
\hline 7 & Nabiala P & 30.0 & 40.0 & 41.43 & 64.78 & IPS & IPA \\
\hline 8 & $\begin{array}{l}\text { Muh. Farid } \\
\text { G }\end{array}$ & 25.0 & 40.0 & 61.43 & 71.03 & IPA & IPA \\
\hline 9 & $\begin{array}{l}\text { Wahyudi } \\
\text { Saputra }\end{array}$ & 20.0 & 45.0 & 58.57 & 67.9 & IPA & IPA \\
\hline 10 & $\begin{array}{l}\text { Feni } \\
\text { Ahmad }\end{array}$ & 30.0 & 45.0 & 44.29 & 59.26 & IPA & IPA \\
\hline 11 & Tresna P & 35.0 & 40.0 & 47.14 & 70.66 & IPA & IPA \\
\hline 12 & Sarmina & 35.0 & 40.0 & 41.43 & 68.09 & IPS & IPA \\
\hline 13 & Tanzani & 45.0 & 70.0 & 58.57 & 75.26 & IPA & IPA \\
\hline$\ldots$ & $\ldots$ & $\ldots$ & $\ldots$ & $\ldots$ & $\ldots$ & $\ldots$ & $\ldots$ \\
\hline 360 & $\begin{array}{l}\text { Muh Akbar } \\
\text { H }\end{array}$ & 20.0 & 20.0 & 52.86 & 82.98 & AGAMA & AGAMA \\
\hline
\end{tabular}

\section{KESIMPULAN}

Penelitian ini menghasilkan akurasi sebesar 88,61\% dan nilai precission dan recall masing-masing adalah 0,903 dan 0,905, angka tersebut jika dilihat dari tingkat diagnose kurva ROC. Kedua algoritma ini termasuk kedalam kategori Excellent Classification dalam penentuan jurusan menggunakan algoritma CART. Sehingga algoritma CART dan C4.5 sangat direkomendasikan untuk mengklasifikasikan penjurusan, dengan catatan jika atribut yang dimiliki dalam penentuan jurusan mayoritas kedalam bentuk numerik maka algoritma CART lebih dianjurkan diterapkan dalam melakukan klasifikasi penjutusan siswa, karena berdasarkan perhitungannya, algoritma CART memang lebih baik untuk menghadapai data-data yang bersifat numerik.

\section{REFERENSI}

[1] Y. S. Nugroho, "Klasifikasi dan Klastering Penjurusan Siswa SMA Negeri 3 Boyolali," Khazanah Inform. J. Ilmu Komput. dan Inform., vol. 1, no. 1, p. 1, 2015.

[2] F. Rini, N. Kahar, and Juliana, "Penerapan Algoritma K-Means Pada Pengelompokan Data Siswa Baru Berdasarkan Jurusan Di Smk Negeri 1 Kota Jambi Berbasis Web ".," Semin. Nas. APTIKOM, pp. 94-99, 2016.

[3] I. M. Prabowo and Subiyanto, "Sistem Rekomendasi Penjurusan Sekolah Menengah Kejuruan Dengan Algoritma C4.5," J. Kependidikan, vol. 1, no. 1, pp. 139-149, 2017.

[4] F. E. Pratiwi, F. E. Pratiwi, and I. Zain, "Klasifikasi Pengangguran Terbuka Menggunakan CART (Classification and Regression Tree) di Provinsi Sulawesi Utara," J. Sains dan Seni ITS, vol. 3, no. 1, pp. D54D59, 2014.

[5] Z. Mutiah, M. Bettiza, and M. R. Rathomi, "Penerapan Algoritma Classification And Regression Tree (CART) Untuk Pemilihan Jurusan SMA (STUDI KASUS : SMA Negeri 3 Bintan Kabupaten Bintan),” pp. $1-13,2015$.

[6] Y. S. Nugroho and N. S. Haryati, "Klasifikasi dan Klastering Penjurusan Siswa SMA Negeri 3 Boyolali," Khazanah Inform. J. Ilmu Komput. dan Inform., vol. 1, no. 1, pp. 1-6, 2015. 
[7] Y. Mardi, "Data Mining: Klasifikasi Menggunakan Algoritma C4.5," J. Edik Inform., vol. 2, no. 1, pp. 213-219, 2014.

[8] J. Han, K. Mao, T. Xu, J. Guo, Z. Zuo, and C. Gao, "A soil moisture estimation framework based on the CART algorithm and its application in China," J. Hydrol., vol. 563, pp. 65-75, 2018.

[9] S. M. Hamze-Ziabari and T. Bakhshpoori, "Improving the prediction of ground motion parameters based on an efficient bagging ensemble model of M5' and CART algorithms," Appl. Soft Comput. J., vol. 68, pp. 147$161,2018$.

[10] M. M. Ghiasi, S. Zendehboudi, and A. A. Mohsenipour, "Decision treebased diagnosis of coronary artery disease: CART model," Comput. Methods Programs Biomed., vol. 192, p. 105400, 2020.

[11] L. L. Doove, S. Van Buuren, and E. Dusseldorp, "Recursive partitioning for missing data imputation in the presence of interaction effects," Comput. Stat. Data Anal., vol. 72, pp. 92-104, 2014.

[12] Mardiani, "Penerapan Klasifikasi Dengan Algoritma Cart Untuk Prediksi Kuliah Bagi Mahasiswa Baru," Semin. Nas. Apl. Teknol. Inf., vol. 2012, no. Snati, pp. 15-16, 2012.

[13] F. E. dan I. Z. Pratiwi, "Klasifikasi Pengangguran Terbuka Menggunakan CART ( Classification and Regression Tree ) di Provinsi Sulawesi Utara," J. Sains Dan Seni Pomits, vol. 3, no. 1, pp. 2337-3520, 2014.

[14] Hariati, M. Wati, and B. Cahyono, "Penerapan Algoritma C4.5 Decision Tree pada Penentuan Penerima Program Bantuan Pemerintah Daerah Kabupaten Kutai Kartanegara," Jurti, vol. 2, no. 1, pp. 27-36, 2018.

[15] A. Naik and L. Samant, "Correlation Review of Classification Algorithm Using Data Mining Tool: WEKA, Rapidminer, Tanagra, Orange and Knime," Procedia Comput. Sci., vol. 85, no. Cms, pp. 662-668, 2016.

[16] emadwiandr, "Sistem Rekomendasi Penjurusan Sekolah Menengah Kejuruan Dengan Algoritma C4.5," J. Chem. Inf. Model., vol. 53, no. 9, pp. 1689-1699, 2013. 